\title{
Некоторые процессуалыные вопросы исполнения мер пресечения в виде запрета определенных действий, домашнего ареста и замога В Аеятельности уголовно-исполнительных инспекций
}

\section{Л. А. КОЛПАКОВА}

Вологодский институт права и экономики ФСИН России, г. Вологда, Российская Федерация

ORCID: https://orcid.org/0000-0002-9937-8462, e-mail: upkiord@yandex.ru

Р е ферат

Введение: статья посвящена анализу процессуальных проблем в деятельности уголовно-исполнительных инспекций в связи с осуществлением контроля за подозреваемыми и обвиняемыми при исполнении мер пресечения в виде домашнего ареста, залога, запрета определенных действий. Цель: на основе обобщения судебной практики, деятельности уголовно-исполнительных инспекций выявить закономерности и процессуальные проблемы, возникающие при реализации отдельных мер принуждения, в рамках исполнения которых уголовно-исполнительные инспекции компетентны осуществлять контроль, а также выработать предложения по устранению правовых пробелов и дать рекомендации организационно-процессуального характера. Методы: применялись общенаучные (формальной и диалектической логики, системного анализа, интерпретации) и частнонаучные методы (историкоправовой, сравнительно-правовой, формально-догматический и метод толкования правовых норм). Результаты: в ходе анализа отечественной и зарубежной юридической практики в сфере избрания и исполнения мер пресечения в виде домашнего ареста, залога, запрета определенных действий выявлены некоторые закономерности и правовые пробелы, требующие законотворческих решений, а также сложности с интерпретацией соответствующих правовых норм и судебных решений в деятельности уголовно-исполнительных инспекций, выдвинуты предложения по преодолению выявленных проблем. Выводы: назначение и исполнение мер пресечения в виде домашнего ареста, запрета определенных действий, залога согласуются с нормами международного права, решениями Европейского суда по правам человека; контрольные функции в отношении подследственных при этом отнесены к компетенции уголовно-исполнительных инспекций, испытывающих затруднения в связи с непроработанностью отдельных механизмов реализации указанных мер принуждения; решение выявленных проблем видится в восполнении правовых пробелов в части некоторых процессуальных полномочий уголовно-исполнительных инспекций и совершенствовании судебной практики в плане достаточной конкретизации судебных решений и четкого выполнения требований законности.

Ключе в ы е слов а : домашний арест; запрет определенных действий; залог; уголовно-исполнительные инспекции; контроль; меры пресечения; судебные решения.

12.00.09 - Уголовный процесс, криминалистика; оперативно-розыскная деятельность.

Для цитирования: Колпакова Л. А. Некоторые процессуальные вопросы исполнения мер пресечения в виде запрета определенных действий, домашнего ареста и залога в деятельности уголовно-исполнительных инспекций. Пенитенциарная наука, 2021, т. 15, № 1 (53), c. 62-73. DOI 10.46741/2686-9754-2021-15-1-62-73.

\section{Some Procedural Issues Related to the Enforcement of Restrictive Measures in the Form of Prohibition on Certain Actions, House Arrest, and Bail in the Work of Probation Inspectorates}

\section{LYUDMILA A. KOLPAKOVA}

Vologda Institute of Law and Economics of FSIN Russia, Vologda, Russian Federation 
ORCID: https://orcid.org/0000-0002-9937-8462, e-mail: upkiord@yandex.ru

A bstract. Introduction: the article analyzes procedural issues in the activities of probation inspectorates in connection with the monitoring of suspects and accused in the execution of restrictive measures in the form of house arrest, bail, prohibition on certain actions. Aim: on the basis of generalization of judicial practice, the activities of probation inspectorates, we identify patterns and procedural problems arising from the implementation of certain measures of coercion, within the framework of which the probation inspectorates are competent to exercise control, as well as to develop proposals for eliminating legal gaps and give organizational recommendations of procedural nature. Methods: general scientific (formal and dialectical logic, system analysis, interpretation) and specific scientific methods (historical legal, comparative legal, formal dogmatic and the method of interpreting legal norms) were used. Results: in the course of the analysis of domestic and foreign legal practice in the field of selection and execution of restrictive measures in the form of house arrest, bail, prohibition on certain actions, some patterns and legal gaps were identified that require legislative decisions, as well as difficulties with the interpretation of relevant legal norms and court decisions in activities of probation inspectorates; proposals were put forward to overcome the identified problems. Conclusions: the appointment and execution of restrictive measures in the form of house arrest, prohibition on certain actions, and bail are consistent with the norms of international law, decisions of the European Court of Human Rights; control functions in relation to persons under investigation are attributed to the competence of probation inspectorates, which are experiencing difficulties due to the lack of elaboration of certain mechanisms for the implementation of these coercive measures; the solution to the identified problems is seen in filling legal gaps in some of the procedural powers of probation inspectorates and improving judicial practice in terms of sufficient specification of court decisions and strict compliance with the requirements of legality.

Ke y w o r d s : house arrest; prohibition on certain actions; bail; penal inspections; the control; preventive measure; court decisions.

12.00.09 - Criminal procedure, criminalistics; intelligence-gathering activity.

For citation: Kolpakova L.A. Some procedural issues of enforcement of restrictive measures in the form of prohibition on certain actions, house arrest and bail in the activities of probation inspectorates. Penitentiary Science, 2021, vol. 15 (53), pp. 6273. DOI 10.46741/2686-9754-2021-15-1-62-73.

\section{Введение}

Федеральная служба исполнения наказаний, как известно, выполняет комплекс разноплановых функций, перечень которых не исчерпывается лишь исполнением уголовных наказаний. Так, в компетенцию и сферу ответственности уголовно-исполнительных инспекций входит контроль в допенальный период за подозреваемыми и обвиняемыми, в отношении которых судом избраны меры пресечения в виде залога, запрета определенных действий и домашнего ареста. Потребность в указанных мерах и в связи с этим новеллизация УПК РФ были вызваны негативной практикой излишне широкого и в ряде случаев необоснованного применения заключения под стражу, что шло вразрез со сложившейся парадигмой гуманизации уголовной политики.

\section{Постановка проблемы и результаты}

Домашний арест (ст. 107 УПК РФ) в ряду мер уголовно-процессуального принуж- дения стоит на втором месте по степени строгости после заключения под стражу. Существенное ограничение свободы подозреваемого или обвиняемого предопределило судебный порядок его избрания. В настоящее время законодатель четко определяет сущность данной пресекательной меры, которая состоит в изоляции от общества без помещения лица в специализированные учреждения, предназначенные для предварительного заключения. Местом содержания лица может быть назначено либо его место жительства, либо при необходимости в лечении лечебное учреждение. Данная мера может быть применена изолированно, а также в совокупности с мерой, предусмотренной ст. 105.1 УПК РФ, с установлением одного или нескольких запретов, о которых подробнее будет сказано ниже. В рамках статьи мы не будем подробно рассматривать порядок применения данной меры, остановимся лишь на некоторых проблемах, возникающих в ходе осуществления 
контроля за подозреваемыми и обвиняемыми со стороны уголовно-исполнительных инспекций.

Несмотря на то что исполнение контрольных функций при применении домашнего ареста в форме, соответствующей действующей правовой конструкции, в целом не вызывает серьезных затруднений у сотрудников инспекции, отдельные вопросы требуют пояснений. Так, в случае госпитализации подозреваемого (обвиняемого), подвергнутого домашнему аресту, сотрудники уголовно-исполнительной инспекции должны уведомить об этом органы предварительного расследования в течение 24 часов. Приказ Минюста России № 189, МВД России № 603, СК России № 87, ФСБ России № 371 от 31.08.2020 «Об утверждении Порядка осуществления контроля за нахождением подозреваемых или обвиняемых в месте исполнения меры пресечения в виде домашнего ареста и за соблюдением возложенных судом запретов подозреваемыми или обвиняемыми, в отношении которых в качестве меры пресечения избран запрет определенных действий, домашний арест или залог» (далее - межведомственный приказ) не дает ответа на вопрос, нужно ли в таких случаях контролирующему органу выходить с ходатайством в суд об изменении места исполнения меры пресечения. Думается, что требуется ответить на него утвердительно, поскольку это обстоятельство является значимым именно в плане осуществления контрольных мер и определения субъектов, привлеченных к этому. Однако чтобы это реализовать, необходимо закрепить данную обязанность уголовно-исполнительных инспекций законодательно в ст. 107 УПК РФ и указанном приказе. Кроме того, следовало бы нормативно установить правило об обязательном уведомлении администрации медицинской организации о характере деяния, в котором подозревается (обвиняется) госпитализированное лицо, и о том, на какую конкретно территорию (здание, отделение или палату) будет распространяться ограничение его передвижения.

Следующий вопрос, требующий реакции законодателя, а также принятия организационных мер, - это правомерность установления судами в решениях о применении домашнего ареста возможности ежедневных прогулок. Примечательно, что и суды, и сотрудники уголовно-исполнительных инспекций воспринимают данный факт как нормальное явление, исходя из соображений разумного соотношения домашнего ареста и заключения под стражу. В последнем случае, как известно, подследственным предоставляется лимитированное время на прогулки в изолированных двориках. В отношении домашнего ареста такой возможности не существует. В связи с этим у сотрудников инспекций закономерно возникают вопросы, каким образом обеспечить контроль во время прогулок, ведь в этот период будет нарушаться главная особенность домашнего ареста - изоляция от общества. По мнению Е. В. Ларкиной, данную проблему можно решить, доставляя подозреваемых (обвиняемых) в специально оборудованные для прогулок места (территории), вместе с тем она сама же обращает внимание на отсутствие финансирования подобных мероприятий [14, с. 132]. Кроме того, если признать право лиц, находящихся под домашним арестом, совершать прогулки, границы домашнего ареста и схожего запрета, предусмотренного п. 1 ч. 6 ст. 105.1 УПК РФ, размываются.

Приведем пример, когда, по нашему мнению, суд проигнорировал не только нормы закона о содержании домашнего ареста и его целевом предназначении, но и не учел характер преступления и личности обвиняемой. Так, Псковский областной суд, рассмотрев апелляционную жалобу защитника обвиняемой Ч. по поводу замены для ее подзащитной домашнего ареста на запрет определенных действий, отказал в ее удовлетворении. Вместе с тем было продлено время ежедневных прогулок с 8.00 до 11.00 в дневное время и с 19.00 до 22.00 в вечернее время. По данным следствия известно и отражено в судебном решении, что Ч. действовала в составе организованной группы, осуществляла незаконную банковскую деятельность, сопряженную с извлечением дохода в особо крупном размере, а также вовлекала в преступную деятельность многочисленные коммерческие организации. Сам же суд, вынесший столь противоречивое решение, установил, что обвиняемая может оказывать влияние на свидетелей (ряд из них давал показания под псевдонимами) и имеет возможность скрыться от следствия [4]. В данной ситуации позиция суда объясняется тем, что прогулки требовались осужденной по медицинским показаниям, но тогда было бы целесообразно избирать запрет определенных действий с 
ограничением времени выхода из жилого помещения.

Уголовно-исполнительные инспекции обязаны реализовать подобные судебные решения в силу подп. 1 п. 7 Положения о Федеральной службе исполнения наказаний, утвержденного указом Президента Российской Федерации от 13.10.2004 № 1314, и обеспечить «точное и безусловное исполнение приговоров, постановлений и определений судов в отношении осужденных, лиц, содержащихся под стражей, и лиц, к которым применена мера пресечения в виде домашнего ареста». Единственно возможной рекомендацией в таких ситуациях является предложение полагаться на технические средства контроля, причем не только те, которые приняты на вооружение ФСИН России, но и городские системы видеонаблюдения.

Контроль за лицами, подвергнутыми мере пресечения в виде залога, осуществляется уголовно-исполнительной инспекцией при одновременном применении к подозреваемому или обвиняемому запретов определенных действий, что регламентировано межведомственным приказом. Фактически в зону контрольных функций инспекции попадает в целом поведение подследственного, за исключением собственно внесения предмета залога.

Залог не является новой мерой уголовно-процессуального принуждения для отечественного законодательства, равно как и прямым заимствованием из зарубежных моделей судопроизводства. Залог известен российскому праву с 1864 г. [25, с. 54-68] и, в отличие от ряда прогрессивных институтов, введенных состоявшейся судебной реформой, не утратил своей актуальности в период становления советской власти. Хотя следует заметить, что позже, вплоть до принятия действующего УПК РФ, данная мера встречала резкую критику как буржуазный пережиток, порождающий неравенство в плане применяемых мер пресечения к подозреваемым и обвиняемым с различным уровнем материального обеспечения. Переосмысление практической и социальной значимости залога в качестве альтернативы заключению под стражу было связано с единым курсом на гуманизацию уголовной и уголовно-процессуальной политики. Стимулом для этого послужило более пристальное внимание в отечественной доктрине и правоприменительной практике к источникам международного права и ре- шениям Европейского суда по правам человека. В частности, в ст. 9 Международного пакта о гражданских и политических правах и ст. 5 Конвенции о защите прав человека и основных свобод закреплено право каждого на замену залогом более строгих мер пресечения, связанных с ограничением свободы, что нашло отражение в преамбуле Постановления Пленума Верховного суда Российской Федерации от 19.12.2013 № 41 «О практике применения судами законодательства о мерах пресечения в виде заключения под стражу, домашнего ареста и залога». В постановлении Европейского суда по правам человека от 10.01.2012 по жалобам № 42525/07 и № 60800/08 «Ананьев и другие (Ananyev and others) против Российской Федерации» [17] отдельно был сделан акцент на структурных проблемах российских учреждений, предназначенных для предварительного заключения под стражу, связанных с колоссальным переполнением камер и нарушением санитарных норм содержания заключенных.

Правовая природа залога в уголовном процессе заключается в создании механизма обеспечения выполнения подозреваемым (обвиняемым) своих процессуальных обязанностей и недопущения с его стороны новых противоправных деяний, а также противодействия производству по делу под угрозой обращения в доход государства принадлежащего ему имущества [1].

Согласно обновленной редакции ст. 106 УПК РФ (Федеральный закон от 07.04.2010 № 60-Ф3 «О внесении изменений в отдельные законодательные акты Российской Федерации») к инициаторам применения залога отнесены лишь обвиняемый, подозреваемый, залогодатель, суд (при отказе в удовлетворении ходатайства о более строгой мере пресечения). Как видим, ни следователь, ни дознаватель, ни представители уголовно-исполнительной инспекции, осуществляющие контроль за лицом, подвергнутым запрету определенных действий или домашнему аресту, не входят в круг уполномоченных субъектов. Логика законодателя здесь вполне очевидна - они не вправе обязать залогодателя внести залог, а иногда и не располагают достаточными сведениями о материальных возможностях подозреваемого (обвиняемого), его окружения. Вместе с тем уполномоченные на заявление ходатайства субъекты вынуждены самостоятельно обращаться в суд и поддержи- 
вать там свою позицию, что для некоторых категорий граждан в силу разных причин затруднительно. В определенных ситуациях им было бы проще действовать через представителей органов предварительного расследования или уголовно-исполнительных инспекций, осуществляющих контрольные функции. Отсюда считаем, что возвращение к предыдущей редакции ч. 2 ст. 106 УПК РФ с включением в круг лиц, имеющих право на обращение в суд за применением залога, дополнительно представителей инспекции расширило бы диспозитивные начала в выборе оптимального способа обращения в суд.

Целесообразно упомянуть и об обратной ситуации, когда требуется возбуждение перед судом ходатайства об изменении меры пресечения в виде залога на более строгую в связи с нарушением подозреваемым (обвиняемым) возложенных на него процессуальных обязанностей. Прежде всего, это касается обеспечения прав потерпевшего, мнение которого, как известно, при избрании мер пресечения, не связанных с изоляцией от общества, никто не спрашивает, что порождает активные дискуссии среди ученых и практиков [7, с. 71; 12, с. 10; 13, с. 11]. Законодатель оставляет выбор конкретной меры воздействия за правоприменителем, даже если высока вероятность угрозы потерпевшему, свидетелю, прочим участникам уголовного судопроизводства (п. 3 ч. 1 ст. 97 УПК РФ).

Отчасти решением данной проблемы стала возможность комбинаторного применения залога и запрета определенных действий, в частности запретов, предусмотренных п. 1-3 ч. 6 ст. 105.1 УПК РФ, обязанность по контролю за исполнением которых возложена на уголовно-исполнительные инспекции. Отметим, что согласно ч. 8.1 ст. 106 УПК РФ залог может комплексно сочетаться с любыми запретами, предусмотренными ч. 6 ст. 105.1 УПК РФ. В этой связи в правоприменительной практике встречаются ошибки, связанные с исчислением сроков их применения. УПК РФ на этот счет дает вполне конкретные предписания. Так, лишь в отношении запрета выходить в определенные периоды времени за пределы жилого помещения (п. 1 ч. 6 ст. 105.1 УПК РФ) сроки действия запрета имеют обособленное исчисление (ч. 10 ст. 105.1 УПК РФ), а сроки остальных запретов, предусмотренных в п. 2-6 ч. 6 ст. 105.1 УПК РФ, полностью со- впадают с периодом действия залога.

Как показал системный анализ положений УПК РФ и межведомственного приказа, выяснение обстоятельств, связанных с соблюдением указанных запретов, является прерогативой дознавателя, следователя, прокурора, суда, представителей уголовноисполнительной инспекции, поскольку в их функционал входит обеспечение гарантий безопасности участников уголовного процесса. При этом правом на обращение в суд с ходатайством об изменении меры пресечения обладают только лица, в чьем производстве находится уголовное дело. Представители инспекции таким полномочием не обладают. В силу положений вышеупомянутого приказа они обязаны сообщать о любых нарушениях запретов подконтрольными лицами следователю или дознавателю, а те в свою очередь должны рассмотреть вопрос о возбуждении перед судом соответствующего ходатайства. Данный порядок представляется оправданным, поскольку именно лицо, ведущее расследование, отвечает за его эффективность. Вместе с тем представители инспекции располагают максимальным объемом информации о поведении подследственного и прочих обстоятельствах, входящих в локальный предмет доказывания при замене меры пресечения. Отсюда представляется целесообразным установить обязанность участия в судебных заседаниях представителей уголовно-исполнительной инспекции при рассмотрении вопросов о замене мер пресечения, в рамках исполнения которых данный орган осуществляет контрольные полномочия. Предлагается закрепить соответствующую норму в ст. 110 УПК РФ, сформировав новую 4. 4.1 .

Говоря о мерах пресечения, в исполнении которых уголовно-исполнительная инспекция принимает непосредственное участие, нельзя не остановиться подробнее на мере в виде запрета определенных действий, относительно недавно получившей прописку в отечественном уголовно-процессуальном законодательстве. Ее введение в перечень мер принуждения федеральным законом от 18.04.2018 № 72-ФЗ в УПК РФ неизбежно вызвало изменения в практике применения залога и домашнего ареста. Последняя из указанных мер претерпела также кардинальную переработку законодательной конструкции. Присутствие в арсенале правоприменителя альтернативных заключению под стражу 
мер пресечения на деле показало их недостаточную эффективность и востребованность, что и вызвало появление в УПК РФ восьмой меры пресечения. Отметим, что ее содержание не является чем-то абсолютно новым для отечественного процессуального законодательства, а выступает результатом усовершенствования существующих пресекательно-превентивных механизмов. В этой связи в научной среде достаточно широко распространено мнение, которое представляется нам справедливым и обоснованным, что запрет определенных действий как мера пресечения производен от домашнего ареста, содержание которого после обновления норм, его регламентирующих, сводится к полной изоляции подозреваемого (обвиняемого) от общества [10, с. $126 ; 11$, с. 117 ; 16, с. 49-50]. Вместе с тем заметим, что «новая» мера пресечения образовалась не в результате механического деления правового материала ст. 107 УПК РФ на две самостоятельные статьи и, соответственно, меры, а явилась результатом анализа потребностей практики и зарубежного опыта применения аналогичных мер принуждения. Более того, в отечественном уголовно-процессуальном праве ранее не было мер пресечения, которые могли бы выполнять как самостоятельную роль, так и применяться субсидиарно по отношению к иным мерам, усиливая их пресекательный и превентивный потенциал [15, с. 113]. Отсюда мы получили принципиально новый механизм индивидуализации мер воздействия на подозреваемого или обвиняемого.

В зарубежном законодательстве и юридической практике подобного рода меры существуют давно и успешно применяются по различным категориям дел, но чаще по делам о насилии в семье (domestic violence), преследовании (harassment), нарушении общественного порядка. Так, в США, Великобритании, Канаде, Австралии, Ямайке, Шотландии и др. ограничительные меры и запреты применяются по судебному решению, которое может быть облечено в форму судебного ордера, охранного судебного приказа (order for protection), запретительного приказа, защитного приказа (restraining order или protective order), приказа о недосаждении (non-molestation order) и т. п. [26; 28; 30; 32-34]. В отличие от отечественной модели меры пресечения в виде запрета определенных действий, зарубежные аналоги, как правило, не ограничены по переч- ню запретов. Чаще определяется лишь вид судебного решения по времени действия (временно или постоянно). В США, к примеру, в силу двухколейной системы законодательства каждый штат вправе определять свою систему запретов. Так, в штате НьюЙорк за получением защитного ордера можно обратиться в три различные судебные инстанции: Семейный суд, Уголовный суд, Верховный суд, причем для первого из них важно наличие официальных семейных взаимоотношений, для второго - наличие возбужденного уголовного дела в отношении абъюзера или преследователя, для третьего актуален действующий бракоразводный процесс. При этом, сравнивая эффективность различных мер воздействия на правонарушителя, большинство представителей зарубежной науки высказываются в пользу психологических мер (установления запретов под угрозой применения более серьезных ограничений) по отношению, к примеру, к кратковременному аресту [29; 31, с. 695], что является закономерным результатом ориентации уголовного судопроизводства стран Европы и Америки на так называемую «парадигму восстановления» [27].

В теоретическом и практическом аспектах актуальным представляется вопрос о месте запрета определенных действий в системе мер пресечения, которые по общему правилу расположены в тексте УПК РФ по мере возрастания их строгости. Соответственно, более строгими следует считать домашний арест и заключение под стражу, менее строгими - залог и все остальные меры пресечения. Однако данная система работает лишь при определенных условиях. Например, если сравнить залог, сопряженный с неудобствами и ограничениями в пользовании и распоряжении имуществом, и запрет на использование Интернета, то вряд ли можно однозначно судить, какая из мер строже. В другом случае, если запрет покидать жилое помещение комбинировать с залогом (ч. 3 ст. 105.1, ч. 1.1 ст. 97 УПК РФ), при надлежащем контроле со стороны уголовно-исполнительной инспекции за подследственным получим меру воздействия едва ли не строже домашнего ареста. Исходя из сказанного можно сделать вывод о значительной серьезности и вариативности данной меры.

С момента введения в действие ст. 105.1 УПК РФ, регламентирующей применение запрета определенных действий, прошло два 
с половиной года. Это достаточный срок для того, чтобы можно было судить об эффективности и востребованности данной меры через призму не только судебно-следственной практики, но и практики уголовно-исполнительных инспекций территориальных органов ФСИН России, обеспечивающих контроль за соблюдением указанной меры.

Общие положительные эффекты от введения запрета определенных действий видятся, во-первых, в сокращении расходов на содержание подозреваемых (обвиняемых) под стражей, а также на выплаты в порядке реабилитации лицам, незаконно или необоснованно подвергнутых предварительному заключению. Во-вторых, считаем справедливым мнение Н. А. Симагиной о том, что применение рассматриваемой меры позволяет избегать шаблонных решений при избрании мер пресечения, что способствует повышению их эффективности [23]. В-третьих, запрет определенных действий является универсальной мерой пресечения в отношении категорий преступлений, пола и возраста подозреваемых и обвиняемых, в отличие от заключения под стражу и домашнего ареста [24]. В-четвертых, может стать тем соломоновым решением, когда строгая мера пресечения нужна, но заключение под стражу или домашний арест утратили свою актуальность в отношении данного подозреваемого (обвиняемого). На последнее обстоятельство обращено внимание в п. 21 Постановления Пленума Верховного Суда Российской Федерации от 19.12.2013 № 41 «О практике применения судами законодательства о мерах пресечения в виде заключения под стражу, домашнего ареста и залога». Результаты анализа ряда судебных апелляционных постановлений об отмене ранее избранной меры пресечения в виде заключения под стражу показывают, что и дознаватели, и следователи, выходя с ходатайством в суд, и суды первой инстанции в своих решениях руководствуются зачастую соображениями целесообразности, не учитывая индивидуальные особенности личности подозреваемого (обвиняемого), его семейное положение, степень общественной опасности инкриминируемого деяния и его самого. С. В. Бурмагин обоснованно замечает, что позиция лиц, ведущих предварительное расследование, часто исходит из соображений удобства работы с подозреваемым (обвиняемым) [8]. Так, решением Кировского районного суда г. Саратова было удовлетворено ходатайство стороны обвинения о заключении обвиняемой под стражу лишь на основании сведений о квалификации деяния и предполагаемых сроках расследования, в связи с чем апелляционным постановлением Саратовского областного суда избранная мера была изменена на запрет определенных действий [2].

Обобщив практику применения меры пресечения в виде запрета определенных действий по различным регионам страны в 2018-2020 гг. (было изучено около ста судебных решений), мы сделали ряд выводов:

- наиболее востребована данная мера пресечения по делам о преступлениях в сфере экономики;

- следователи и дознаватели относительно редко инициируют применение запрета определенных действий, гораздо чаще данная мера избирается судом по своей инициативе при отказе в применении более строгих мер пресечения или продлении их сроков;

- часто (около 70 \% случаев) практикуется назначение от 3-5 запретов одновременно, что вызывает сложности при осуществлении контроля со стороны уголовно-исполнительной инспекции;

- в 7 \% судебных решений встречались случаи назначения запретов, не предусмотренных ч. 6 ст. 105.1 УПК РФ; отмечены отдельные случаи возложения на сотрудников подразделений ФСИН России несвойственных для них функций (например, контроль за исполнением запрета на управление транспортным средством);

- суды крайне редко назначают запрет находиться в определенных местах, а также ближе установленного расстояния до определенных объектов, посещать определенные мероприятия и участвовать в них;

- в ряде случаев судебные решения по поводу содержания запретов недостаточно конкретны, что затрудняет или делает невозможным контроль за их исполнением со стороны уголовно-исполнительной инспекции (например, при ограничении круга общения подозреваемых (обвиняемых) используются обобщенные, допускающие расширительное толкование формулировки типа «...и других сотрудников предприятия...», «...и так далее»).

Так, например, Постановлением Верховного Суда Республики Дагестан от 12.02.2020 обвиняемому С. мера пресечения в виде заключения под стражу была из- 
менена на запрет определенных действий с 12 февраля 2020 г. сроком на 3 месяца 00 суток, то есть до 12 мая 2020 г. с установлением следующих запретов: «...общение со всеми свидетелями, представителем потерпевшего, участвующего в данном уголовном деле, а также с обвиняемыми по делу и их защитниками...» [3]. Отсутствие в судебном решении указания на конкретных лиц, с которыми запрещается или ограничивается общение, делает невозможным для уголовно-исполнительной инспекции исполнение соответствующих запретов. Здесь отметим, что в законодательной конструкции ч. 7 ст. 105.1 УПК РФ использована формулировка «указываются конкретные условия исполнения этой меры пресечения... данные о лицах, с которыми запрещено общаться...», то есть о наличии правового пробела здесь говорить не приходится. Вместе с тем во избежание вольного толкования данной формулировки представляется целесообразным детализировать ее, изложив в следующей редакции: «данные о лицах, с которыми запрещено общаться, с указанием сведений, позволяющих их персонифицировать, а также процессуального статуса».

В другом примере суд не учел ограничений компетенции уголовно-исполнительной инспекции в исполнении запретов, установленных в ч. 11 ст. 105.1 УПК РФ, и возложил на заместителя начальника Котласского межмуниципального филиала ФКУ «УИИ УФСИН России по Архангельской области» [19] обязанность осуществлять контроль за исполнением запрета управлять автомобилем и иным транспортным средством в отношении подозреваемого в совершении преступления, предусмотренного ст. 264 УК РФ. Примечательно, что указанная процессуальная норма не называет субъекта, который полномочен осуществлять контроль в данном случае (представляется, что это должна быть государственная инспекция безопасности дорожного движения), но из компетенции ФСИН России данная функция прямо исключена. В данном случае следует констатировать наличие пробела в правовом регулировании наряду с очевидной судебной ошибкой. Вместе с тем в соответствии с процессуальными канонами до тех пор, пока судебное решение никем не обжаловано и не вступит в силу иное законное решение, предыдущее считается истинным и обязательным к исполнению сотрудниками инспекции. Другой вопрос, каким обра- зом судебное решение подлежит исполнению в отсутствие объективной возможности и необходимых административных функций у подразделений ФСИН России?

Следующий пример касается некорректного комбинаторного применения запретов, предусмотренных ч. 6 ст. 105.1 УПК РФ, и других мер пресечения. Магаданский областной суд назначил обвиняемому меру пресечения в виде домашнего ареста с одновременным наложением ряда запретов, в том числе покидать без письменного разрешения лица, осуществляющего расследование по уголовному делу, и контролирующего органа место жительства, за исключением одного часа прогулки с 11 до 12 часов ежедневно в районе места жительства [21]. Здесь, во-первых, представляется излишним указание на данный запрет, поскольку он нивелируется более строгими условиями исполнения домашнего ареста и, согласно ч. 7 ст. 107 УПК РФ, его применение не предусмотрено. В специальной литературе приводятся однозначные суждения об их взаимоисключающем характере [6; 9, с. 125]. Во-вторых, суд в своем решении допустил смешение содержания избираемой меры пресечения с содержанием подписки о невыезде и надлежащем поведении. Аналогичные ошибки замечены нами также в решениях Нерюнгринского городского суда Республики Саха [20] (Якутия) и Горно-Алтайского городского суда [18].

Подобного рода судебные решения существенно затрудняют работу контролирующих органов, в частности уголовно-исполнительных инспекций, которые иногда оказываются заложниками ситуации. Не выполнить судебное решение они не могут, но и фактическая реализация становится по объективным причинам невозможной. Отсюда требуется выработка предложений по преодолению таких ситуаций. Прежде всего видится необходимой дача разъяснений Пленума Верховного Суда Российской Федерации по вопросам, отраженным в настоящей статье. Однако адресатом данных разъяснений выступают в основном суды. Для подразделений ФСИН России, задействованных в исполнении мер пресечения в виде залога, запрета определенных действий, домашнего ареста, представляются возможными следующие рекомендации.

Если в поступивших на исполнение в уголовно-исполнительную инспекцию судебных решениях выявляются явные несоот- 
ветствия действующему процессуальному законодательству, сотрудник инспекции имеет следующие варианты разрешения данной ситуации:

1. Он вправе обратиться в прокуратуру с указанием на обнаруженные обстоятельства, а именно нарушение законности при вынесении судебных решений. Однако в этом случае, скорее всего, заявителя переадресуют в соответствующую судебную инстанцию.

2. Сотрудник может обратиться в суд с апелляционной жалобой в порядке ст. 389.1 УПК РФ, поскольку в ее части первой право обжалования судебного решения предоставляется любым «лицам в той части, в которой обжалуемое судебное решение затрагивает их права и законные интересы». Отметим, что прецеденты судебного обжалования уголовно-исполнительной инспекцией от своего имени судебных решений имеются [5].

3. Инспекция может выразить свою правовую позицию по поводу невозможности исполнить судебное решение путем направления начальником инспекции представления в суд по аналогии с механизмом замены меры пресечения, установленным межведомственным приказом в случае ее нарушения. Однако при этом суд не сможет отменить свое же судебное решение, и в конечном итоге придется прибегнуть ко второму способу разрешения ситуации.

4. В юридической литературе предлагается действовать через институт разрешения судом вопросов, связанных с исполнением приговора, а по аналогии и иного судебного решения (п. 15 ст. 397 УПК РФ) путем подачи сотрудником уголовно-исполнительной инспекции представления (ст. 399 УПК РФ). Так, результаты анкетирования сотрудников инспекций, проведенного А. А. Рукавишниковым, показали, что в большинстве случаев (97 \%) с целью устранения сомнений и неясностей при исполнении судебных актов в суд обращались именно представители данно- го органа, в $2 \%$ - адвокаты осужденного и в $1 \%$ - иные суды. Такие обращения касались уточнения времени суток, когда осужденному запрещалось уходить из дома, устранения ошибок, допущенных в судебном решении при написании персональных данных подконтрольных лиц, описок и арифметических ошибок, если они очевидны и исправление их не может вызвать сомнение [22]. Вместе с тем представляется, что такой механизм возможен, если не нарушено требование законности и необходимо исправить лишь техническую ошибку, не влияющую на суть самого решения, например когда нужно уточнить адрес, инициалы лица и т. п.

\section{Выводы}

Таким образом, контроль за подозреваемыми, обвиняемыми со стороны уголовно-исполнительной инспекции при применении мер процессуального принуждения в виде залога, запрета определенных действий, домашнего ареста выступает самостоятельным направлением деятельности, требующим повышенного внимания не только к самим подконтрольным лицам, но и к судебным решениям, отличающимся значительной вариабельностью в перечне устанавливаемых ограничений и запретов. Правовую регламентацию порядка осуществления контроля следует признать достаточно удачной. Вместе с тем ряд моментов требует разъяснений, а иногда и дополнительной детализации процессуальных и иных правовых норм. Некоторые вопросы, возникающие в деятельности инспекций в связи с исполнением судебных решений, поступающих на исполнение, могут быть разрешены путем обращения к уже имеющимся процессуальным механизмам и институтам в целях обеспечения законности, обоснованности, справедливости, а также эффективности мер принуждения в виде залога, запрета определенных действий, домашнего ареста.

\section{СПИСОК ЛИТЕРАТУРЫ}

1. Авдеева, Е. В. Залог в механизме регулирования уголовно-процессуальных отношений / Е. В. Авдеева, Р. С. Тамаев // Актуальные проблемы адвокатской практики. - 2019. - № 2 (39). - С. 48-52.

2. Апелляционное постановление Саратовского областного суда № 22К-2391/2018 от 22.06.2018 // Судебные и нормативные акты Российской Федерации. - URL: http://sudact.ru/regular/doc (дата обращения: 20.01.2021).

3. Апелляционное постановление Верховного Суда Республики Дагестан от 28.05.2020. Дело № 22к-869/2020 // Судебные и нормативные акты Российской Федерации. - URL: https://sudact.ru (дата обращения: 02.02.2021).

4. Апелляционное постановление № 22-464/2020 22К-464/2020 от 29.06.2020 по делу № 3/12-44/2020 // Судебные и нормативные акты Российской Федерации. - URL: https://sudact.ru/regular/ doc/5LMtriZWbk5x/?regulartxt=Черневич\&regular-case_doc=Дело+№++22-++ 614\&regular-lawchunkinfo=\&regular-date_from=\&regular-date_to= 
\&regular-w or kflow_stage=20\&regular-area=\&regular-court=Псковский+областной + суд+\%2 8Псковская+область \%29\&regular-judge=\&_=1614525830542\&snippet_pos=82\#snippet (дата обращения: 02.02.2021).

5. Апелляционное постановление № 22-754/2017 от 11.05.2017 по делу № 22-754/2017 // Судебные и нормативные акты Российской Федерации. - URL: https://sudact.ru/regular/doc/QpsbldooQldO/ (дата поступления: 21.01.2021). 6. Бондаренко, И. П. Особенности применения «комбинированных» мер пресечения / И. П. Бондаренко // Современное уголовно-процессуальное право - уроки истории и проблемы дальнейшего реформирования: материалы международной научно-практической конференции. В 2 томах. Том 1. - Орел : Орловский юридический институт МВД России им. В. В. Лукьянова, 2019. - С. 42-49.

7. Брусницын, Л. Меры пресечения по УПК РФ: новеллы и старые ошибки / Л. Брусницын // Уголовное право. 2002. - № 3. - С. 70-72.

8. Бурмагин, С. В. Как обосновать переход на альтернативную меру пресечения. Когда следователь ходатайствует о заключении под стражу / С. В. Бурмагин // Уголовный процесс. - 2018. - № 10. - С. 60-61.

9. Вастьянова, О. Д. Эффективность применения запрета определенных действий / О. Д. Вастьянова // Криминалистика: вчера, сегодня, завтра. - 2020. - № 1 (13). - С. 122-128.

10. Гершевский, Ю. Р. Некоторые вопросы избрания меры пресечения в виде запрета определенных действий / Ю. Р. Гершевский // Вестник Калининградского филиала Санкт-Петербургского университета МВД России. 2019. - № 2 (56). - С. 126-128.

11. Головинская, И. В. Запрет определенных действий как новелла уголовно-процессуальных мер пресечения / И. В. Головинская, И. И. Савельев // Ученые записки. - 2018. - № 4 (28). - С. 117-133.

12. Колдин, С. В. Защита прав и законных интересов потерпевшего по Уголовно-процессуальному кодексу Российской Федерации : автореферат диссертации на соискание ученой степени кандидата юридических наук / Колдин Сергей Владимирович. - Саратов, 2004. - 25 с.

13. Корнелюк, О. В. Баланс процессуальных статусов потерпевшего и обвиняемого при досудебном производстве : автореферат диссертации на соискание ученой степени кандидата юридических наук / Корнелюк Оксана Владимировна. - Нижний Новгород, 2003. - 26 с.

14. Ларкина, Е. В. Запрет определенных действий и предусмотренные им запреты в сочетании с залогом и домашним арестом: первые полгода применения / Е. В. Ларкина // Lex russica. - 2019. - № 4. - C. 129-138. DOI: 10.17803/1729-5920.2019.149.4.129-138.

15. Николюк, В. В. Новые правила зачета в срок наказания времени содержания лица под стражей, изоляции от общества при применении мер пресечения в виде домашнего ареста, запрета определенных действий / В. В. Николюк // Вестник Восточно-Сибирского института МВД России. - 2018. - № 4 (87). - С. 112-121.

16. Орлов, А. В. Актуальные проблемы реализации домашнего ареста в свете введения меры пресечения в виде запрета определенных действий / А. В. Орлов // Вестник Самарского юридического института. - 2018. - № 3 (29). С. $48-51$.

17. Постановление ЕСПЧ от 10.01.2012 «Дело «Ананьев и другие (Ananyev and others) против Российской Федерации»» (жалоба № 42525/07, 60800/08) // Бюллетень Европейского Суда по правам человека. - 2012. - № 8.

18. Постановление Горно-Алтайского городского суда Республики Алтай от 17.08.2018 по материалу № 3/411/18 // Государственная автоматизированная система Российской Федерации «Правосудие». - URL: sudrf.ru (дата обращения: 02.02.2021).

19. Постановление Красноборского районного суда Архангельской области от 25.07.2018 по делу № 3/141/18 // Судебные и нормативные акты Российской Федерации. - URL: https://sudact.ru (дата обращения: 02.02.2021).

20. Постановление Нерюнгринского городского суда Республики Саха (Якутия) от 20.09.2018 по материалу № 3/3105/2018 // Государственная автоматизированная система Российской Федерации «Правосудие». - URL: sudrf.ru (дата обращения: 02.02.2021).

21. Постановление Магаданского областного суда от 04.10.2018 по материалу № 2k-13/2018 (уголовное дело № 11701440010000018). - URL: https://sudact.ru (дата обращения: 27.02.2021).

22. Рукавишникова, А. А. Устранение сомнений и неясностей в приговоре (определении, постановлении), поступившем на исполнение в УИИ / А. А. Рукавишникова // Студенческие реферативные статьи и материалы. - URL: https:// studref.com/410533/pravo/ustranenie_somneniy_neyasnostey_prigovore_opredelenii_postanovlenii_postupivshem_ ispolnenie (дата обращения: 21.01.2021).

23. Симагина, Н. А. Обстоятельства, учитываемые при избрании меры пресечения в виде запрета определенных действий / Н. А. Симагина // Адвокатская практика. - 2020. - № 3. - С. 42-46.

24. Стельмах, В. Ю. Мера пресечения «запрет определенных действий» / В. Ю. Стельмах // Российский следователь. - 2020. - № 2. - С. 21-25.

25. Фойницкий, И. Я. Курс уголовного судопроизводства. В 2 томах. Том 1 / И. Я. Фойницкий. - Санкт-Петербург, 1996. - 579 с.

26. Antisocial Behaviour etc. (Scotland) Act 2004: Guidance on Antisocial Behaviour Orders. - URL: https://www.gov.scot/ publications/antisocial-behaviour-etc-scotland-act-2004-guidance-antisocial-behaviour-orders/ (дата обращения: 02.02.2021).

27. Ashworth, A. The criminal process. An evaluative study / A. Ashworth. - Oxford, 1994. - Pp. 34-35.

28. Do you know a woman who is being abused? A legal rights handbook. - URL: https://docplayer.net/14004397-Do-youknow-a-woman-who-is-being-abused.html (дата обращения: 02.02.2021).

29. McCord, J. Deference of domestic violence: a critical view of research / J. McCord // Journal of recerch in crime and delinquency. - 1972. - Volume 29, no. 2. - Pp. 229-239.

30. Non-molestation order: family law decisions. - URL: https://www.familylawdecisions.co.uk/useful-information/nonmolestation-order (дата обращения: 02.02.2021).

31. Pate, A. M. Formal and informal deterrence to domestic violence: The Dade county spouse assault experiment / A. M. Pate, E. E. Hamilton // American Sotiological Review. - 1992. - Volume 57, no. 5. - Pp. 691-697.

32. Family Law Act 1996. Part IV Non-molestation orders Section 42. - URL: http://www.legislation.gov.uk/ (дата обращения: 02.02.2021).

33. What are the differences between a peace bond and a restraining order? BC Ministry of Attorney General. Archived from the original on June 16, 2002. Retrieved August 22, 2016. - URL: https://stepstojustice.са (дата обращения: C2021). 
34. What is a peace bond? A legal information resource from Legal Aid Ontario. - URL: http://lawfacts.ca/node/26 (дата обращения: 02.02.2021).

\section{REFERENCES}

1. Avdeeva E.V., Tamaev R.S. Bail in the mechanism of regulation of criminal procedure relations. Aktual'nye problemy advokatskoi praktiki=Topical Issues of Lawyer Practice, 2019, no. 2 (39), pp. 48-52. (In Russ.).

2. Appeal resolution of the Saratov Oblast Court no. 22K-2391/2018 of June 22, 2018. Judicial and regulatory acts of the Russian Federation. Available at: http://sudact.ru/regular/doc (accessed January 20, 2021). (In Russ.).

3. Appeal resolution of the Supreme Court of the Republic of Dagestan of May 28, 2020. Case no. 22k-869/2020. Judicial and regulatory acts of the Russian Federation. Available at: https://sudact.ru (accessed February 2, 2021). (In Russ.).

4. Appeal resolution no. 22-464 / 2020 22K-464/2020 of June 29, 2020, Case no. 3/12-44/2020. Judicial and regulatoryacts of the Russian Federation. Available at: https://sudact.ru/regular/ doc/5LMtriZWbk5x/?regular-txt=Chernevich\&regularcase_doc=Delo+№++22-++ 614\&regular-lawchunkinfo=\&regular-date_from=\&regular-date_to=\&regular-w or kflow_stage $=20 \&$ regular-area $=\&$ regular-court=Pskovskii+oblastnoi+sud $+\quad \% 2 \quad 8$ Pskovskaya+oblast' \%29\&regularjudge $=\& \_=1614525830542 \&$ snippet_pos $=8$ 2\#snippet (accessed February 2, 2021). (In Russ.).

5. Appeal resolution no. 22-754/2017 of May 11, 2017, Case no. 22-754/2017. Judicial and regulatory acts of the Russian Federation. Available at: https://sudact.ru/regular/doc/QpsbldooQIdO/ (accessed January 21, 2021). (In Russ.).

6. Bondarenko I.P. Features of the application of "combined" preventive measures. Sovremennoe ugolovno-protsessual'noe pravo - uroki istorii i problemy dal'neishego reformirovaniya: materialy mezhdunarodnoi nauchno-prakticheskoi konferentsii. $V 2$ tomakh. Tom 1 [Modern criminal procedure law - history lessons and problems of further reform. Proceedings of the international research-to-practice conference. In 2 volumes. Volume 1]. Oryol: Orlovskii yuridicheskii institut MVD Rossii im. V. V. Luk'yanova, 2019. Pp. 42-49. (In Russ.).

7. Brusnitsyn L. Measures of restraint under the Criminal Procedure Code of the Russian Federation: novels and old mistakes. Ugolovnoe pravo=Criminal Law, 2002, no. 3, pp. 70-72. (In Russ.).

8. Burmagin S.V. Kak obosnovat' perekhod na al'ternativnuyu meru presecheniya. Kogda sledovatel' khodataistvuet o zaklyuchenii pod strazhu How to justify the transition to an alternative pre-trial restrictions. When the investigator petitions for detention. Ugolovnyi protsess=Criminal Procedure, 2018, no. 10, pp. 60-61. (In Russ.).

9. Vast'yanova O.D. Effectiveness of the application of the prohibition of certain actions. Kriminalistika: vchera, segodnya, zavtra=Criminalistics: Yesterday, Today, Tomorrow, 2020, no. 1 (13), pp. 122-128. (In Russ.).

10. Gershevskii Yu.R. Some issues of choosing a preventive measure in the form of a ban on certain actions. Vestnik Kaliningradskogo filiala Sankt-Peterburgskogo universiteta MVD Rossii=Bulletin of the Kaliningrad Branch of Saint Petersburg University of the Ministry of Internal Affairs of Russia, 2019, no. 2 (56), pp. 126-128. (In Russ.).

11. Golovinskaya I.V., Savel'ev I.I. Prohibition of certain actions as a novella of criminal procedural restrictive measures. Uchenye zapiski=Academic Notes, 2018, no. 4 (28), pp. 117-133. (In Russ.).

12. Koldin S.V. Zashchita prav i zakonnykh interesov poterpevshego po Ugolovno-protsessual'nomu kodeksu Rossiiskoi Federatsii: avtoreferat dissertatsii na soiskanie uchenoi stepeni kandidata yuridicheskikh nauk [Protection of the rights and legitimate interests of the victim under the Criminal Procedure Code of the Russian Federation: Candidate of Sciences (Law) dissertation abstract]. Saratov, 2004. 25 p.

13. Kornelyuk O.V. Balans protsessual'nykh statusov poterpevshego i obvinyaemogo pri dosudebnom proizvodstve: avtoreferat dissertatsii na soiskanie uchenoi stepeni kandidata yuridicheskikh nauk [Balance of procedural statuses of the victim and the accused in pre-trial proceedings: Candidate of Sciences (Law) dissertation abstract]. Nizhny Novgorod, 2003. 26 p.

14. Larkina E.V. Ban of certain actions and prohibitions stipulated in combination with bail and house arrest: the first six months of application. Lex Russica, 2019, no. 4, pp. 129-138. DOI: 10.17803/1729-5920.2019.149.4.129-138. (In Russ.). 15. Nikolyuk V.V. New regulations for including in the sentence the time of the individual's detention, isolation from society in the application of measures of restraint in the form of house arrest, prohibition of certain actions. Vestnik VostochnoSibirskogo instituta MVD Rossii=Bulletin of the East Siberian Institute of the Ministry of Internal Affairs of Russia, 2018, no. 4 (87), pp. 112-121. (In Russ.).

16. Orlov A.V. Actual problems of implementing house arrest in the light of the introduction of a preventive measure in the form of a ban on certain actions. Vestnik Samarskogo yuridicheskogo instituta=Bulletin of Samara Law Institute, 2018, no. 3 (29), pp. 48-51. (In Russ.).

17. ECHR ruling of January 10, 2012 "The case of Ananyev and others v. the Russian Federation" (complaint no. 42525/07, 60800/08). Byulleten' Evropeiskogo Suda po pravam cheloveka=Bulletin of the European Court of Human Rights, 2012, no. 8. (In Russ.).

18. Resolution of the Gorno-Altaisk City Court of the Altai Republic of August 17, 2018 on material no. 3/411/18. "Pravosudie" state automated system of the Russian Federation. Available at: sudrf.ru (accessed February 27, 2021). (In Russ.).

19. Resolution of the Krasnoborsky District Court of the Arkhangelsk Oblast of July 25, 2018, Case no. 3/141/18. Judicial and regulatory acts of the Russian Federation. Available at: https://sudact.ru (accessed February 27, 2021). (In Russ.). 20. Resolution of the Neryungrinsky City Court of the Republic of Sakha (Yakutia) of September 20, 2018 on material no. 3/3-105/2018. "Pravosudie" state automated system of the Russian Federation. Available at: sudrf.ru (accessed February 27, 2021). (In Russ.).

21. Resolution of the Magadan Regional Court of October 4, 2018 on material no. 2k-13/2018 (criminal case no. 11701440010000018). Available at: https://sudact.ru (accessed February 27, 2021). (In Russ.).

22. Rukavishnikova A.A. Elimination of doubts and ambiguities in the sentence (definition, resolution) received for execution in the penal system. Student abstract articles and materials. Available at: https://studref.com/410533/pravo/ustranenie _somneniy neyasnostey_prigovore_opredelenii_postanovlenii_postupivshem_ispolnenie (accessed January 21, 2021). (In Russ.).

23. Simagina N.A. Circumstances taken into account when choosing a preventive measure in the form of a ban on certain actions. Advokatskaya praktika=Lawyer Practice, 2020, no. 3, pp. 42-46. (In Russ.).

24. Stel'makh V.Yu. Measure of restraint: "prohibition of certain actions". Rossiiskii sledovatel'=Russian Investigator, 2020, no. 2, pp. 21-25. (In Russ.).

25. Foinitskii I.Ya. Kurs ugolovnogo sudoproizvodstva. V 2 tomakh. Tom 1 [Course of criminal justice. In 2 volumes. Volume 1]. Saint Petersburg, 1996. 579 p. (In Russ.). 
26. Antisocial Behaviour etc. (Scotland) Act 2004: Guidance on Antisocial Behaviour Orders. Available at: https://www. gov.scot/publications/antisocial-behaviour-etc-scotland-act-2004-guidance-antisocial-behaviour-orders/ (accessed February 2, 2021).

27. Ashworth A. The criminal process. An evaluative study. Oxford, 1994. Pp. 34-35.

28. Do you know a woman who is being abused? A legal rights handbook. Available at: https://docplayer.net/14004397Do-you-know-a-woman-who-is-being-abused.html (accessed February 2, 2021).

29. McCord J. Deference of domestic violence: a critical view of research. Journal of Research in Crime and Delinquency, 1972, vol. 29, no. 2, pp. 229-239.

30. Non-molestation order: family law decisions. Available at: https://www.familylawdecisions.co.uk/useful-information/ non-molestation-order (accessed February 2, 2021).

31. Pate A.M., Hamilton E.E. Formal and informal deterrence to domestic violence: the Dade county spouse assault experiment. American Sociological Review, 1992, vol. 57, no. 5, pp. 691-697.

32. Family Law Act 1996. Part IV Non-molestation orders Section 42. Available at: http://www.legislation.gov.uk/ (accessed February 2, 2021).

33. What are the differences between a peace bond and a restraining order? BC Ministry of Attorney General. Archived from the original on June 16, 2002. Retrieved August 22, 2016. Available at: https://stepstojustice.ca

34. What is a peace bond? A legal information resource from Legal Aid Ontario. Available at: http://lawfacts.ca/node/26 (accessed February 2, 2021).

\section{СВЕДЕНИЯ ОБ АВТOPE / INFORMATION ABOUT THE AUTHOR}

ЛЮДМИЛААЛЕКСЕЕВНА КОЛПАКОВА - канДиДат ЮрИдических наук, доцент, заместитель начальника кафедры уголовного процесса, криминалистики и оперативнорозыскной деятельности юридического факультета Вологодского института права и экономики ФСИН России, г. Вологда, Российская Федерация. ORCID: https://orcid. org/0000-0002-9937-8462, e-mail: upkiord@yandex.ru
LYUDMILA A. KOLPAKOVA - Candidate of Sciences (Law), Associate Professor, deputy head of the Department of Criminal Proceedings, Criminalistics and IntelligenceGathering Activity, Faculty of Law, Vologda Institute of Law and Economics of FSIN Russia, Vologda, Russian Federation, ORCID: https://orcid.org/0000-0002-99378462, e-mail: upkiord@yandex.ru 